\title{
Effect of sustained physiologic hyperinsulinaemia and hyperglycaemia on insulin secretion and insulin sensitivity in man
}

\author{
S.Del Prato ${ }^{2}$, F. Leonetti ${ }^{1}$, D.C. Simonson ${ }^{3}$, P.Sheehan ${ }^{1}$, M.Matsuda ${ }^{1}$, R. A. DeFronzo ${ }^{1}$ \\ ${ }^{1}$ Diabetes Division, University of Texas Health Science Center and Audie L. Murphy VA Hospital, San Antonio, Texas, USA \\ ${ }^{2}$ Cattedra di Malattie del Ricambio, University of Padova, Padova, Italy \\ ${ }^{3}$ Joslin Diabetes Center, Brigham and Women's Hospital and Harvard Medical School, Boston, MA, USA
}

Summary Two study protocols to examine the effects of chronic (72-96 h) physiologic euglycaemic hyperinsulinaemia $(+72 \mathrm{pmol} / \mathrm{l})$ and chronic hyperglycae$\operatorname{mic}(+1.4 \mathrm{mmol} / \mathrm{l})$ hyperinsulinaemia $(+78 \mathrm{pmol} / \mathrm{l})$ on insulin sensitivity and insulin secretion were performed in 15 healthy young subjects. Subjects received a three-step euglycaemic insulin (insulin infusion rates $=1.5,3$, and $\left.6 \mathrm{nmol} \cdot \mathrm{kg}^{-1} \cdot \mathrm{min}^{-1}\right)$ clamp and a hyperglycaemia $(6.9 \mathrm{mmol} / \mathrm{l})$ clamp before and after chronic insulin or glucose infusion. Following 4 days of sustained euglycaemic hyperinsulinaemia whole body glucose disposal decreased by $20-40 \%$. During each insulin clamp step, the defect in insulin action was accounted for by impaired non-oxidative glucose disposal $(p<0.01)$. Chronic euglycaemic hyperinsulinaemia did not alter insulin-mediated suppression of hepatic glucose production. Following insulin infusion the ability of hyperglycaemia to stimulate insulin secretion was significantly diminished. Following $72 \mathrm{~h}$ of chronic glucose infusion (combined hyperglycaemic hyperinsulinaemia), there was no change in whole body glucose disposal. However, glucose oxidation during each insulin clamp step was significantly increased and there was a reciprocal decline in non-oxidative glucose disposal by $25-39 \%$ $(p<0.01)$; suppression of hepatic glucose production by insulin was unaltered by chronic hyperglycaemic hyperinsulinaemia. Chronic glucose infusion increased the plasma insulin response to acute hyperglycaemia more than twofold. These results demonstrate that chronic, physiologic hyperinsulinaemia, whether created by exogenous insulin infusion or by stimulation of endogenous insulin secretion, leads to the development of insulin resistance, which is characterized by a specific defect in the non-oxidative (glycogen synthetic) pathway. These findings indicate that hyperinsulinaemia should be considered, not only as a compensatory response to insulin resistance, but also as a self-perpetuating cause of the defect in insulin action. [Diabetologia (1994) 37: 10251035]

Key words Chronic hyperinsulinaemia, chronic hyperglycaemia, insulin resistance, insulin secretion, impaired glycogen synthesis.
Received: 25 January 1994

and in revised form: 28 April 1994

Corresponding author: R. A. DeFronzo, M.D. Chief, Diabetes Division University of Texas Health Science Center 7703 Floyd Curl Drive, San Antonio, Tx 78284-7886, USA

Abbreviations: NIDDM, Non-insulin-dependent diabetes mellitus; CRC, Clinical Research Center; Rd, rate of glucose disappearance; Ra, rate of glucose appearance; HGP, hepatic glucose production; NPRQ, non-protein respiratory quotient; $\mathrm{CV}$, coefficient of variation.
Insulin resistance is a characteristic feature of non-insulin dependent diabetes mellitus NIDDM and antedates the onset of impaired glucose tolerance [1-5]. Early in the natural history of NIDDM the beta cell responds to the presence of insulin resistance by augmenting its insulin secretion. The resultant hyperinsulinaemia is sufficient to offset the defect in insulin action and maintain normal or only slightly impaired glucose tolerance $[1,2,4-9]$. The hyperinsulinaemia can be viewed as a protective mechanism which enhances glucose flux into the cell and maintains nor- 
mal glucose tolerance $[1,2]$. However, it has been implicated as part of an intertwined metabolic and cardiovascular syndrome characterized by hypertension, dyslipidaemia, coronary artery disease, obesity, NIDDM and insulin resistance [3, 10-12]. From this standpoint the hyperinsulinaemia can be viewed as having serious consequences, especially with regard to the development of atherosclerotic cardiovascular complications.

Hyperinsulinaemia itself has also been implicated in the development of insulin resistance. Thus, chronic hyperinsulinaemia has been shown to induce insulin resistance in some [13-18], but not all [19-21] studies. Little information is available concerning the effect of chronic hyperinsulinaemia on insulinmediated glucose metabolism in man $[16,17]$ and the intracellular metabolic pathway(s) responsible for the reduction in insulin-mediated glucose disposal following chronic exposure to the hormone have not been examined. If chronic, sustained elevated plasma insulin levels are, indeed, a cause of insulin resistance, then the "compensatory" hyperinsulinaemia in NIDDM can no longer be viewed as an adaptive mechanism responsible for the maintenance of normal glucose tolerance, but rather as a self-perpetuating cause of the diabetic condition.

Hyperglycaemia is a hallmark feature of diabetes mellitus and has been incriminated as a self-perpetuating cause of the diabetic condition [22]. Sustained hyperglycaemia has been shown to impair insulin secretion $[23,24]$ and to induce insulin resistance $[1$, 25]. Moreover, the impairment in insulin action is reversible with phlorizin [26], a drug which lowers the plasma glucose by inhibiting renal tubular glucose transport. One study in man has demonstrated that as little as $24 \mathrm{~h}$ of moderate hyperglycaemia can induce insulin resistance [27]. Thus, it is possible that both hyperglycaemia and hyperinsulinaemia, which have been used as biochemical markers for diabetes and insulin resistance, respectively, actually may represent self-perpetuating factors in the pathogenesis of NIDDM.

In this study we have employed the euglycaemic insulin clamp technique in combination with indirect calorimetry and tritiated glucose to define the tissues (i.e., liver vs peripheral) and intracellular pathways (i. e., glucose oxidation vs glycogen synthesis) responsible for the defect in insulin action following chronic sustained physiologic hyperinsulinaemia and hyperglycaemia in healthy young volunteers.

\section{Subjects and methods}

Subjects. Fifteen healthy Caucasian subjects (12 male, 3 female) (age, $27 \pm 2$ years, body mass index, $23.1 \pm 0.6 \mathrm{~kg} / \mathrm{m}^{2}$ ) were studied. Their height, weight, and surface area were $176 \pm 2 \mathrm{~cm}, 71.8 \pm 2.7 \mathrm{~kg}$, and $1.88 \pm 0.04 \mathrm{~m}^{2}$, respectively. All subjects had a normal oral glucose tolerance test, none were taking any medications, and none had a family history of diabetes. Eight subjects participated in the chronic insulin infusion study and seven in the chronic glucose infusion study (see below). None of the subjects participated in any unusual or heavy exercise programs and none were excessively sedentary. Subjects consumed an isocaloric diet, containing approximately $200 \mathrm{~g}$ of carbohydrate for 3 days before study. Before the study the purpose, nature, and potential risks were explained to all subjects and informed, written, voluntary consent was obtained. The protocol was approved by the Institutional Review Boards and the Radiation Safety Committees of The University of Texas Health Science Center and the Yale University School of Medicine.

Experimental design. All studies were performed at the Clinical Research Center (CRC) and, unless otherwise specified, were started at 08.00 hours following a $10-12$ h overnight fast. Each subject initially participated in two studies which were performed in randomized order at 3-5 day intervals.

Euglycaemic insulin clamp. A 20-gauge Teflon catheter was inserted into an antecubital vein and used for the infusion of all test substances. A second catheter was inserted retrogradely into a dorsal vein of the hand for blood sampling and the hand was inserted into a heated box $\left(65^{\circ} \mathrm{C}\right)$. Catheters were kept patent with normal $(0.9 \%)$ saline. At 08.00 hours (time $=-120 \mathrm{~min})$ a prime $(15 \mu \mathrm{Ci})$-constant $(0.15 \mu \mathrm{Ci} / \mathrm{min})$ infusion of $\left[3-{ }^{3} \mathrm{H}\right]$-D-glucose (New England Nuclear, Boston, Mass., USA) was started and continued throughout the study. After a $120 \mathrm{~min}$ equilibration period $(\mathrm{t}=0 \mathrm{~min})$ a $6 \mathrm{~h}$, three step euglycaemic insulin clamp was performed. Insulin was infused sequentially at rates $1.5,3$, and $6 \mathrm{nmol} \cdot \mathrm{kg}^{-1} \cdot \mathrm{min}^{-1}$ for $2 \mathrm{~h}$ each. Arterialized plasma glucose samples were obtained at 5 min intervals and used to adjust a $20 \%$ glucose infusion to maintain euglycaemia [28]. Arterialized blood samples for plasma glucose specific activity and insulin concentration were obtained at $-30,-20,-15,-10,-5$, and 0 min before and every $10-15 \mathrm{~min}$ during the insulin clamp. Blood was promptly centrifuged and plasma decanted and stored at $-20^{\circ} \mathrm{C}$ until analysed. During the last $60 \mathrm{~min}$ of the basal period and of each insulin clamp step, oxygen consumption and carbon dioxide production rates were measured by continuous indirect calorimetry (Vista System, Vacumed, Ventura, Calif., USA) and the data were used to compute rates of glucose and lipid oxidation [29]. The rate of protein oxidation was estimated from the urinary nitrogen excretion during the baseline and insulin-stimulated periods.

Hyperglycaemic clamp. Catheters were inserted into an antecubital vein and into a dorsal hand vein as described above. The hand for blood sampling was inserted into a heated $\left(65^{\circ} \mathrm{C}\right)$ box. A priming glucose infusion was administered in a logarithmically falling manner over the initial $15 \mathrm{~min}$ to acuteIy raise the plasma glucose by $6.9 \mathrm{mmol} / \mathrm{l}$ above the baseline value [28]. Thereafter, plasma glucose was determined at 5 min intervals and a variable glucose infusion was adjusted to maintain the plasma glucose level at $6.9 \mathrm{mmol} / 1$ above the fasting level [28] for $120 \mathrm{~min}$, Blood samples for plasma insulin were obtained at $-30,-20,-10,0 \mathrm{~min}$ in the baseline period and at 2, 4, 6, 8, 10 and every 10 min following the start of glucose infusion.

Chronic insulin infusion. (Fig. 1). Within 3-5 days after the insulin and hyperglycaemic clamp studies, eight subjects were admitted (Day 0) to the CRC. At 18.00 hours (Day 0) they were started on a weight-maintaining diet $(55 \%$ carbohydrate, $30 \%$ fat, $15 \%$ protein) with the calories divided as $1 / 5$, 


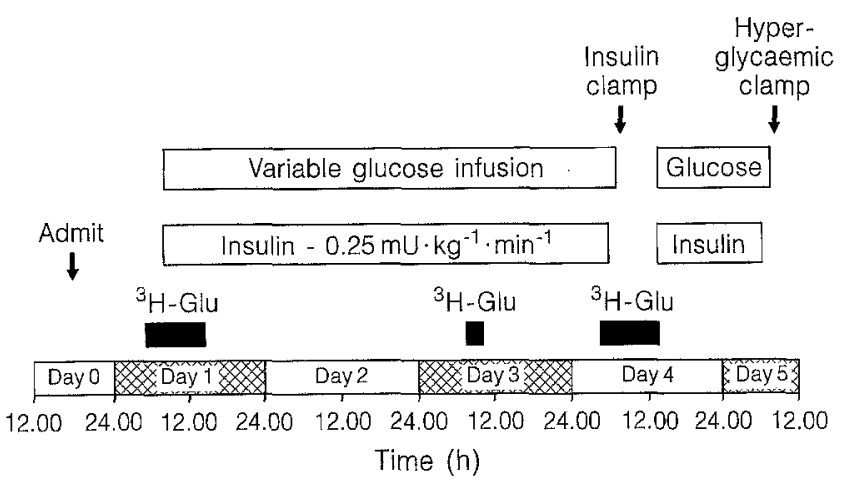

Fig. 1. Design for the chronic insulin infusion (euglycaemic hyperinsulinaemia) protocol

$2 / 5$ and $2 / 5$ between breakfast, lunch, and dinner. A small bedtime snack was permitted. This dietary meal plan was continued throughout the hospital stay. Breakfast was not allowed on the mornings of the repeat euglycaemic insulin (Day 4) and hyperglycaemic (Day 5) clamps. Body weight at the beginning $(73.6 \pm 3.8 \mathrm{~kg})$ and end $(73.7 \pm 4.0 \mathrm{~kg})$ of the 5 day study period was similar.

At 06.00 hours on Day 1 catheters were placed into an antecubital and into a wrist vein of the same arm as described above and a prime $(15 \mu \mathrm{Ci})$-continuous $(0.15 \mu \mathrm{Ci} / \mathrm{min})$ infusion of $\left[3-{ }^{3} \mathrm{H}\right]-\mathrm{D}-$ glucose was given for $8 \mathrm{~h}$. Following a $2 \mathrm{~h}$ basal equilibration period, i. e. at 08.00 hours, a continuous insulin infusion was started at $1.5 \mathrm{nmol} \cdot \mathrm{kg}^{-1} \cdot \mathrm{min}^{-1}$ for $6 \mathrm{~h}$ and plasma glucose was maintained at the basal level. Plasma samples for determination of tritiated glucose specific activity and insulin were obtained at $-30,-20,-15,-10,-5$, and $0 \mathrm{~min}$ in the baseline period and every 10-15 min during the $6 \mathrm{~h}$ insulin-infusion period. This study design allowed us to determine the time course of acute, sustained, physiologic euglycaemic hyperinsulinaemia on hepatic glucose production (HGP) and peripheral glucose disposal. After $6 \mathrm{~h}$ the tritiated glucose infusion was discontinued and the insulin infusion was continued for an additional 4 days at $1.5 \mathrm{nmol} \cdot \mathrm{kg}^{-1} \cdot \mathrm{min}^{-1}$. During this period the plasma glucose was determined every $1-2 \mathrm{~h}$ and an exogenous glucose infusion was adjusted to maintain the plasma glucose concentration at the basal level. The antecubital catheter was changed every $48 \mathrm{~h}$ for sterility purposes. The subjects were attached to a portable insulin/glucose infusion system throughout the study and were encouraged to be fully mobile.

At 08.00 hours on Day 3 , a prime $(15 \mu \mathrm{Ci})$-continuous $(0.15 \mu \mathrm{Ci} / \mathrm{min}) 2 \mathrm{~h}$ infusion of tritiated glucose was given with plasma samples being obtained at 5 min intervals during the final 30 min for determination of plasma tritiated glucose specific activity and insulin concentration. The purpose of this study was to determine if the suppressive effect of physiologic hyperinsulinaemia on hepatic glucose production and whole body glucose uptake had become resistant to insulin.

At 04.00 hours on Day 4 , a prime $(15 \mu \mathrm{Ci})$-continuous $(0.15 \mu \mathrm{Ci} / \mathrm{min})$ infusion of tritiated glucose was started. Plasma samples for tritiated glucose specific activity and insulin were obtained at $5 \mathrm{~min}$ intervals from $05.30-06.00$ hours. At 06.00 hours the constant insulin infusion was discontinued and the glucose infusion was gradually tapered over $60-90 \mathrm{~min}$ to achieve constant fasting plasma glucose and insulin levels. At 08.00 hours the three-step euglycaemic insulin clamp was repeated as described.

Following completion of the euglycaemic insulin clamp, the constant insulin infusion $\left(1.5 \mathrm{nmol} \cdot \mathrm{kg}^{-1} \cdot \mathrm{min}^{-1}\right)$ was restarted and an exogenous glucose infusion was begun to keep the plas- ma glucose concentration constant at each subject's fasting glucose level. At 06.00 hours on Day 5, the constant insulin infusion was stopped and the cold glucose infusion tapered over $60-90 \mathrm{~min}$. At 08.00 hours on Day 5, the hyperglycaemic $(+6.9 \mathrm{mmol} / \mathrm{l})$ clamp was repeated.

Chronic glucose infusion. Within 3-5 days after the euglycaemic insulin and hyperglycaemic clamp studies, seven different subjects were admitted to the CRC (Day 0). Dietary intake and activity were similar to those during the chronic insulin infusion protocol. At 06.00 hours on Day 1, a prime-continuous infusion of $\left[3-{ }^{3} \mathrm{H}\right]$-D-glucose was initiated as described above and continued for $8 \mathrm{~h}$. At 08.00 hours a glucose infusion was started at the rate of $16.7 \mu \mathrm{mol} \cdot \mathrm{kg}^{-1} \cdot \mathrm{min}^{-1}$. Plasma tritiated glucose specific activity and insulin concentration were determined at $5-10 \mathrm{~min}$ intervals during the last $30 \mathrm{~min}$ of the basal tracer equilibration period and at 10-15 min intervals during the subsequent $6 \mathrm{~h}$. At 14.00 hours the tritiated glucose infusion was stopped and the cold glucose infusion was continued at $16.7 \mu \mathrm{mol} \cdot \mathrm{kg}^{-1} \cdot \mathrm{min}^{-1}$ until the end of the 4 day study (except as specified below). Plasma glucose and insulin were determined every $1-2 \mathrm{~h}$ for the following 4 days.

At 08.00 hours on Day 2, i.e. $24 \mathrm{~h}$ after the start of glucose infusion, a $2 \mathrm{~h}$ prime-continuous infusion of tritiated glucose was again administered and plasma samples were obtained at 5 min intervals from $09.30-10.00$ hours for determination of plasma tritiated glucose-specific activity and insulin concentration. The purpose of this study was to determine whether $24 \mathrm{~h}$ of sustained hyperglycaemic hyperinsulinaemia was associated with the development of hepatic and/or peripheral insulin resistance.

At 04.00 hours on Day 3 , the prime-continuous infusion of tritiated glucose was restarted and plasma samples for tritiated glucose specific activity and insulin were obtained at 5 min intervals from 05.30 to 06.00 hours. At 06.00 hours on Day 3 the constant glucose infusion was gradually discontinued and the plasma glucose allowed to fall to fasting levels over the subsequent 60-90 min. At 08.00 hours the $6 \mathrm{~h}$, threestep euglycaemic insulin clamp was repeated with indirect calorimetry. After completion of the insulin clamp study, the constant glucose infusion $\left(16.7 \mu \mathrm{mol} \cdot \mathrm{kg}^{-1} \cdot \mathrm{min}^{-1}\right)$ was resumed.

At 06.00 hours on Day 4 the constant glucose infusion was again gradually tapered and the plasma glucose allowed to fall to the fasting level. At 08.00 hours on Day 4 , i.e. $72 \mathrm{~h}$ after start of the constant glucose infusion, the $+6.9 \mathrm{mmol} / 1$ hyperglycaemic clamp was repeated as previously described.

Plasma lipid concentrations were determined at 08.00 hours on Day 1, i.e. prior to the start of the chronic glucose infusion, and at 08.00 hours on Day 3 and Day 4. Subjects remained fully mobile throughout the study. Body weight at the beginning $(69.8 \pm 4.1 \mathrm{~kg})$ and end $(69.9 \pm 4.1 \mathrm{~kg})$ of the 4 day study period was unchanged.

Analytical determinations. Plasma glucose was determined in duplicate by the glucose oxidase method on a Beckman Glucose Analyzer II (Beckman Instruments, Inc., Fullerton, Calif., USA). For the determination of plasma glucose specific activity $(\mathrm{CV}, 4.0 \%)$, the plasma was deproteinized [30] and centrifuged for $20 \mathrm{~min}$ at $4,000 \mathrm{~g}$. The supernatant was evaporated to dryness (Speed-Vac Evaporator, Beckman Instruments) resuspended in $1 \mathrm{ml}$ of distilled water, mixed with $10 \mathrm{ml}$ of Scintiverse II (Fischer Scientific, N.J. USA) and counted in a Beckman LS 5000 scintillation counter (Beckman Instruments). To ensure that all of the non-evaporated radioactivity represented glucose, the tracer infusate and plasma samples collected at time 0 and at the end of insulin clamp were processed by an HPLC method that specifically isolates 
S. Del Prato et al.: Chronic hyperinsulinaemia induces insulin resistance

only glucose [31] and radiochromatograms were performed. No radioactive contaminant was observed in any specimen. Plasma insulin concentration (CV, $3.5 \%$ ) was determined in duplicate by radioimmunoassay [32]. Plasma triglycerides $(\mathrm{CV}, 2.6 \%)$ and total cholesterol $(\mathrm{CV}, 1.7 \%)$ were determined as previously described [33].

Calculations. During all studies in which tritiated glucose was infused, a steady-state plateau of tracer-specific activity was achieved during the last $30 \mathrm{~min}$ of the equilibration period and each insulin clamp step. During repeat studies involving tracer administration, a plasma sample for residual radioactivity was obtained prior to the start of $3{ }^{3} \mathrm{H}$-glucose infusion and this background radioactivity was subtraced from all plasma samples. Under fasting conditions, the rate of whole body glucose disposal $(\mathrm{Rd})$ equals the rate of endogenous (hepatic) glucose appearance $(\mathrm{Ra})$ :

$\mathrm{Ra}=\frac{\left[3-{ }^{3} \mathrm{H}\right]-\mathrm{D}-\mathrm{glucose} \text { infusion rate }(\mathrm{dpm} / \mathrm{min})}{\text { Plasma glucose specific activity }(\mathrm{dpm} / \mathrm{mg})}$

When insulin/glucose are acutely infused, non-steady-state conditions prevail and rates of whole body glucose appearance and disappearance are calculated using Steele's equation [34]. Under these non-steady-state conditions HGP is calculated by subtracting the rate of exogenous cold glucose infusion from the total body $\mathrm{Ra}$. Following $24 \mathrm{~h}$ of insulin/glucose infusion metabolic and tracer steady-state conditions exist and whole body Rd equals $\mathrm{Ra}$, which in turn equals the tritiated glucose infusion rate divided by the steady-state plateau of tritiated glucose-specific activity. HGP is calculated by subtracting the exogenous glucose infusion rate from the whole body $\mathrm{Ra}$. The metabolic clearance rate of insulin during each insulin clamp step was calculated as: constant insulin infusion rate divided by the steady-state plasma insulin concentration minus the basal plasma insulin concentration.

Whole body rates of carbohydrate and lipid oxidation were calculated from the non-protein respiratory quotient as previously described [29]. The rate of non-oxidative glucose disposal, which primarily reflects muscle glycogen synthesis [35], was calculated by subtracting the rate of carbohydrate oxidation (indirect calorimetry) from the rate of whole body glucose utilization.

During the hyperglycaemic clamp HGP is completely suppressed [36] and the rate of exogenous glucose infusion, after correction for urinary glucose loss and for over- or underfilling of the glucose space (both corrections less than $0.83 \mu \mathrm{mol} \cdot \mathrm{kg}^{-1} \cdot \mathrm{min}^{-1}$ ), equals the rate of whole body disposal. In response to the hyperglycaemic stimulus, the plasma insulin response is biphasic with an early burst of insulin release during the first $10 \mathrm{~min}$ followed by a gradually increasing plasma insulin response over the subsequent $110 \mathrm{~min}$. The early (0-10 $\mathrm{min})$, late (10-120 min), and total (0-120 min) plasma insulin responses are calculated as the time weighted mean of all plasma insulin determinations during the respective time intervals. The amount of glucose metabolized (M) divided by the total plasma insulin (I) response provides an index of insulin-mediated glucose disposal under hyperglycaemic conditions.

\section{Statistical analysis}

Since each subject served as their own control for the studies performed before and after chronic glucose and chronic insulin infusion, the Student's $t$-test for paired data or analysis of variance were used for comparison. All data are expressed as the mean \pm SEM.

\section{Results}

\section{Chronic insulin infusion}

Plasma glucose and insulin concentrations. Fasting plasma glucose and insulin were $4.8 \pm 0.1 \mathrm{mmol} / \mathrm{l}$ and $48 \pm 6 \mathrm{pmol} / \mathrm{h}$, respectively. During the $6 \mathrm{~h}$ following start of the chronic insulin infusion, mean plasma insulin concentration increased to $120 \pm 12 \mathrm{pmol} / \mathrm{l}$, while plasma glucose was maintained at $4.8 \pm$ $0.1 \mathrm{mmol} / 1$ with a $\mathrm{CV}$ less than $5 \%$ in all subjects. The mean fasting plasma insulin during chronic insulin infusion on days 1,2 , and 3 was: $114 \pm 12$, $120 \pm 12$, and $120 \pm 12 \mathrm{pmol} / \mathrm{l}$, respectively; the mean fasting plasma glucose was $4.8 \pm 0.1,4.8 \pm 0.1$, and $4.8 \pm 0.1 \mathrm{mmol} / \mathrm{l}$, respectively, with a $\mathrm{CV}$ less than $5 \%$ in all subjects.

Hepatic glucose production (HGP) and glucose disappearance $(R d)$. On the morning of Day 1 , immediately prior to the start of insulin infusion, basal HGP averaged $11.5 \pm 0.6 \mu \mathrm{mol} \cdot \mathrm{kg}^{-1} \cdot \mathrm{min}^{-1}$. During the 0 2, 2-4, and 4-6 h periods following the start of insulin infusion HPG declined to $3.1 \pm 1.0,1.1 \pm 0.9$, and $1.1 \pm 0.6 \mu \mathrm{mol} \cdot \mathrm{kg}^{-1} \cdot \mathrm{min}^{-1}$, respectively. After 48 and $72 \mathrm{~h}$ of continuous insulin infusion, HGP averaged $1.4 \pm 0.6$ and $0.9 \pm 0.8 \mu \mathrm{mol} \cdot \mathrm{kg}^{-1} \cdot \mathrm{min}^{-1}$ (Fig. 1). Basal Rd (11.5 $\left.\pm 0.6 \mu \mathrm{mol} \cdot \mathrm{kg}^{-1} \cdot \mathrm{min}^{-1}\right)$ rose progressively to $14.2 \pm 1.1,18.2 \pm 2.0$, and $22.1 \pm$ $1.9 \mu \mathrm{mol} \cdot \mathrm{kg}^{-1} \cdot \mathrm{min}^{-1}$, respectively, during the $0-2$, $2-4$, and $4-6 \mathrm{~h}$ periods following the start of insulin infusion ( $p<0.01$ for each $\mathrm{Rd}$ vs the previous value). After $48 \mathrm{~h}$ and $72 \mathrm{~h}$ of constant insulin infusion, whole body $\mathrm{Rd}$ decreased to $18.2 \pm 1.5 \mu \mathrm{mol} \cdot \mathrm{kg}^{-1}$. $\min ^{-1}(p<0.01$ vs $6 \mathrm{~h}$ insulin infusion) and to $15.9 \pm 1.4 \mu \mathrm{mol} \cdot \mathrm{kg}^{-1} \cdot \min ^{-1}(p<0.02$ vs $48 \mathrm{~h}$ insulin infusion) (Fig. 2).

Euglycaemic insulin clamp. During the baseline insulin clamp study, the fasting plasma insulin $(42 \pm 6 \mathrm{pmol} / \mathrm{l})$ was raised to $150 \pm 18,240 \pm 12$, and $498 \pm 30 \mathrm{pmol} / 1$ during the $1.5,3$, and $6 \mathrm{nmol} \cdot \mathrm{kg}^{-1}$. $\mathrm{min}^{-1}$ insulin infusion steps, while the fasting plasma glucose $(4.9 \pm 0.1 \mathrm{mmol} / 1)$ was maintained at $4.8 \pm 0.1,4.8 \pm 0.1$, and $5.0 \pm 0.2 \mathrm{mmol} / 1$, respectively. The CVs for plasma glucose and insulin concentration were less than $5 \%$ and $7 \%$, respectively, in each subject during each insulin infusion rate. During the repeat insulin clamp study performed after $72 \mathrm{~h}$ of constant insulin infusion, the basal plasma insulin $(48 \pm 6 \mathrm{pmol} / \mathrm{l})$ was raised to $150 \pm 18,252 \pm 12$, and $498 \pm 24 \mathrm{pmol} / \mathrm{l}$, respectively, during the three insulin clamp steps, while the fasting plasma glucose $(4.8 \pm 0.1 \mathrm{mmol} / \mathrm{l})$ was maintained at $4.9 \pm 0.2$, $4.8 \pm 0.1$, and $4.8 \pm 0.1 \mathrm{mmol} / \mathrm{l}$, respectively.

During the initial insulin clamp, basal HPG $\left(12.7 \pm 1.1 \mathrm{\mu mol} \cdot \mathrm{kg} \cdot{ }^{-1} \mathrm{~min}^{-1}\right)$ declined to $2.5 \pm 0.6$, $0.1 \pm 0.1$, and $0.3 \pm 0.1 \mu \mathrm{mol} \cdot \mathrm{kg} \cdot{ }^{-1} \mathrm{~min}^{-1}$, respective- 

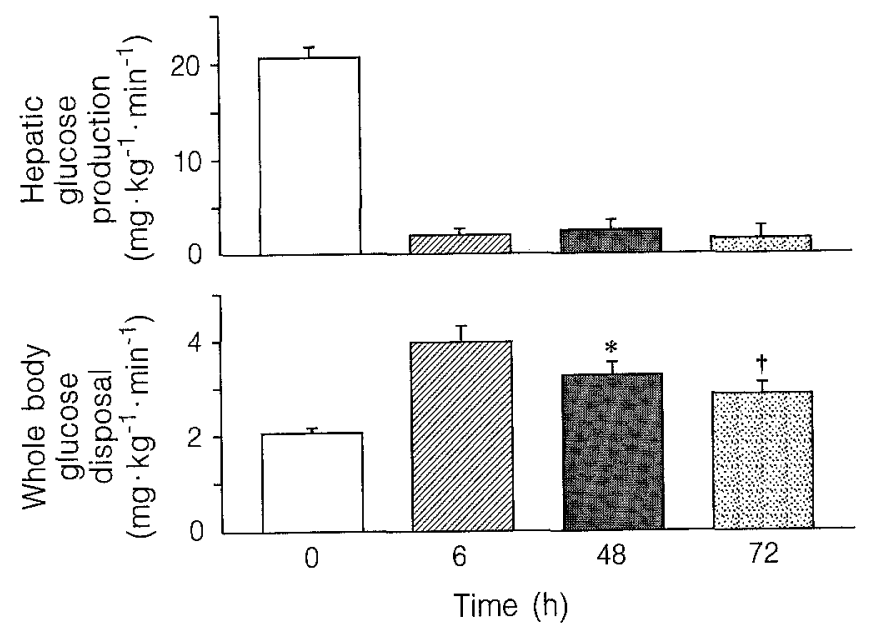

Fig. 2. Time-dependent effect of chronic, sustained physiologic hyperinsulinaemia on HGP and whole body glucose disposal (Rd). Turnover studies were carried out in the basal state and at 6,48 and $72 \mathrm{~h}$ after the start of the constant insulin infusion. ${ }^{*} p<0.01$ vs preceding $\mathrm{Rd} ; \uparrow p<0.02$ vs preceding $\mathrm{Rd}$

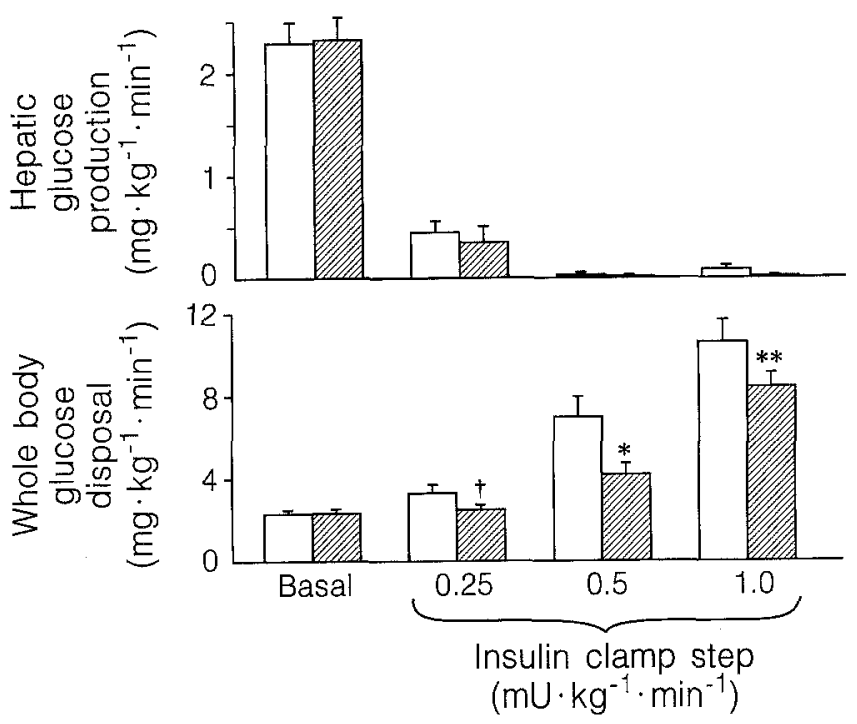

Fig. 3. Effect of chronic, sustained, physiologic hyperinsulinaemia on HGP (upper panel) and whole body glucose disposal $\mathrm{Rd}$ (lower panel) in the basal state and during the three-step euglycaemic insulin clamp. $* p<0.01, \dagger p<0.01, * * p<0.02$ for the insulin clamp studies carried out after (国) vs before ( $\square$ ) chronic insulin infusion

ly, during the $1.5,3$, and $6 \mathrm{nmol} \cdot \mathrm{kg}^{-1} \cdot \mathrm{min}^{-1}$ insulin infusion steps. During the repeat insulin clamp carried out after $72 \mathrm{~h}$ of constant insulin infusion basal $\mathrm{HPG} \quad\left(12.9 \pm 0.1 \mu \mathrm{mol} \cdot \mathrm{kg} \cdot{ }^{-1} \mathrm{~min}^{-1}\right)$ declined to $1.9 \pm 0.9,0.1 \pm 0.1$, and $0.1 \pm 0.1 \mu \mathrm{mol} \cdot \mathrm{kg} \cdot{ }^{-1} \mathrm{~min}^{-1}$, respectively. There were no differences in insulinmediated suppression of HGP between the insulin clamp studies performed before and after 3 days of chronic insulin infusion.

Basal Rd $\left(12.7 \pm 0.1 \mu \mathrm{mol} \cdot \mathrm{kg} \cdot{ }^{-1} \mathrm{~min}^{-1}\right)$ during the initial insulin clamp study rose to $18.2 \pm 2.2$, $37.8 \pm 5.4$, and $58.8 \pm 6.1 \mu \mathrm{mol} \cdot \mathrm{kg} \cdot{ }^{-1} \mathrm{~min}^{-1}$, respec- tively, during the $1.5,3$ and $6 \mathrm{nmol} \cdot \mathrm{kg}^{-1} \cdot \mathrm{min}^{-1}$ insulin infusion steps $(p<0.001$ vs each preceding step) (Fig.3). During the repeat insulin clamp study performed after $72 \mathrm{~h}$ of constant insulin infusion, basal $\mathrm{Rd}\left(12.9 \pm 1.1 \mu \mathrm{mol} \cdot \mathrm{kg} \cdot{ }^{-1} \mathrm{~min}^{-1}\right)$ rose to $13.8 \pm 1.4$, $23.2 \pm 3.1$, and $46.8 \pm 3.8 \mathrm{umol} \cdot \mathrm{kg} \cdot{ }^{-1} \mathrm{~min}^{-1}$ (Fig. 3). These values were $25 \%(p<0.01), 40 \%(p<0.001)$, and $20 \%(p<0.02)$ lower than during the same hyperinsulinaemic step of the initial insulin clamp protocol. Basal glucose oxidation $\left(6.2 \pm 1.1 \mu \mathrm{mol} \cdot \mathrm{kg} \cdot{ }^{-1}\right.$ $\left.\mathrm{min}^{-1}\right)$ increased to $6.7 \pm 1.0 \quad(p=\mathrm{NS}), 13.2 \pm 1.0$ $(p<0.01$ vs basal and preceding step), and $15.3 \pm 1.3$ ( $p<0.05$ vs basal and prior insulin clamp step) (Fig. 4). Following $72 \mathrm{~h}$ of continuous insulin infusion basal glucose oxidation $\left(10.8 \pm 1.2 \mu \mathrm{mol} \cdot \mathrm{kg} \cdot{ }^{-1} \mathrm{~min}^{-1}\right)$ was significantly increased $(p<0.01)$ compared to the basal rate of glucose oxidation prior to the start of the insulin infusion. The rate of glucose oxidation during each insulin clamp step was also significantly increased following chronic insulin infusion: $13.9 \pm 1.4 \quad(p<0.001), \quad 16.5 \pm 1.0 \quad(p<0.05)$, and $18.7 \pm 0.9(p<0.05) \mu \mathrm{mol} \cdot \mathrm{kg} \cdot{ }^{-1} \mathrm{~min}^{-1}$ (Fig. 4). The metabolic clearance rate of insulin during the three steps of the insulin clamp studies performed before and after chronic insulin infusion were similar $(13.9 \pm 1.0$ vs $11.4 \pm 0.9,15.1 \pm 1.2$ vs $13.2 \pm 0.8$, and $13.2 \pm 1.4 \mathrm{vs} 13.2 \pm 1.2 \mathrm{ml} \cdot \mathrm{kg}^{-1} \cdot \mathrm{min}^{-1}$ ).

Basal non-oxidative glucose disposal, $6.4 \pm$ $1.5 \mu \mathrm{mol} \cdot \mathrm{kg} \cdot{ }^{-1} \mathrm{~min}^{-1}$, increased to $10.8 \pm 2.6$, $24.5 \pm 4.8$, and $43.7 \pm 4.0 \mu \mathrm{mol} \cdot \mathrm{kg} \cdot{ }^{-1} \mathrm{~min}^{-1}$ (each $p<0.001$ vs the preceding value) during the $1.5,3$, and $6 \mathrm{nmol} \cdot \mathrm{kg}^{-1} \cdot \mathrm{min}^{-1}$ insulin clamp steps, respectively. Following $72 \mathrm{~h}$ of constant insulin infusion the basal rate of non-oxidative glucose disposal decreased to $2.2 \pm 0.9 \mu \mathrm{mol} \cdot \mathrm{kg} \cdot{ }^{-1} \mathrm{~min}^{-1} \quad(p<0.01$ vs baseline) and the insulin-stimulated rate of non-oxidative glucose disposal was significantly reduced during each of the three insulin clamp steps: $2.1 \pm 1.8$ $(p<0.001), \quad 7.6 \pm 3.7 \quad(p<0.001), \quad$ and $30.5 \pm 3.2$ $(p<0.01) \mu \mathrm{mol} \cdot \mathrm{kg} \cdot{ }^{-1} \mathrm{~min}^{-1}$ (Fig. 4$)$.

Basal lipid oxidation $(0.99 \pm 0.15 \mu \mathrm{mol} \cdot \mathrm{kg}$. $\left.{ }^{-1} \mathrm{~min}^{-1}\right)$ decreased to $0.84 \pm 0.09(p<0.05$ vs basal $)$, $0.23 \pm 0.09 \quad(p<0.01$ vs preceding step), and $0.27 \pm 0.15 \mu \mathrm{mol} \cdot \mathrm{kg} \cdot{ }^{-1} \mathrm{~min}^{-1}$, respectively, during the $1.5,3$, and $6 \mathrm{nmol} \cdot \mathrm{kg}^{-1} \cdot \mathrm{min}^{-1}$ insulin clamp steps. Following $72 \mathrm{~h}$ of constant insulin infusion basal lipid oxidation was reduced to $0.50 \pm 0.14 \mu \mathrm{mol}$. $\mathrm{kg} \cdot{ }^{-1} \mathrm{~min}^{-1}$ and lipid oxidation during each insulin clamp step was also significantly reduced: $0.26 \pm$ $0.15, \quad 0.15 \pm 0.10$, and $0.09 \pm 0.03 \mu \mathrm{mol} \cdot \mathrm{kg} \cdot{ }^{-1} \mathrm{~min}^{-1}$ $(p<0.05)$.

Hyperglycaemic clamp. The fasting plasma glucose, $4.8 \pm 0.1 \mathrm{mmol} / 1$, was acutely raised and maintained at $11.6 \pm 0.2$ and $11.8 \pm 0.1 \mathrm{mmol} / 1(\mathrm{CV}<7 \%)$, respectively, in the hyperglycaemic clamp studies performed before and after $96 \mathrm{~h}$ of constant insulin infusion. Fasting plasma insulin, $48 \pm 6 \mathrm{pmol} / 1$, was similar 

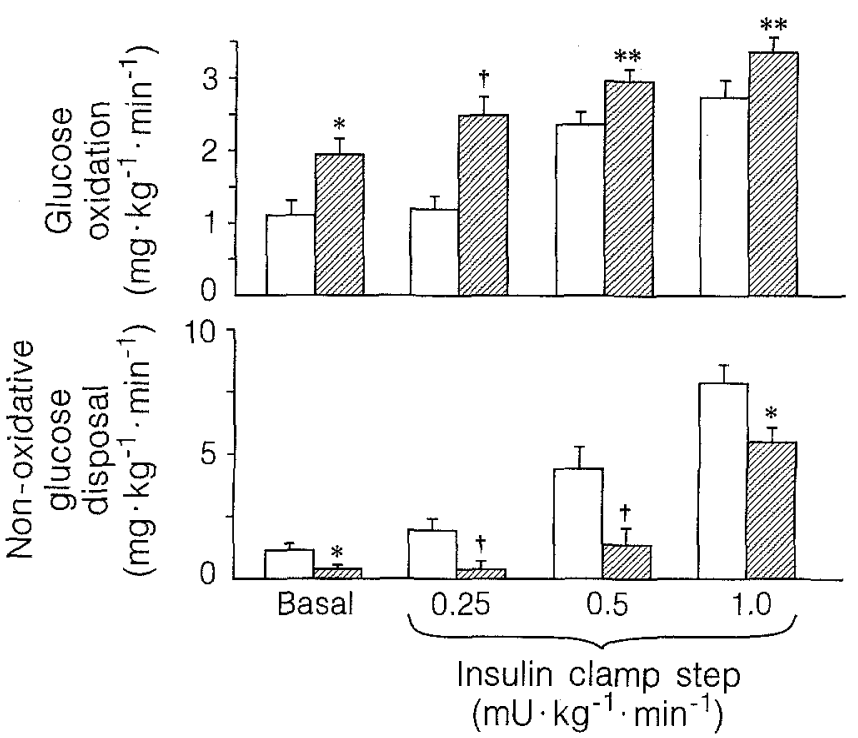

Fig. 4. Effect of chronic, sustained, physiologic hyperinsulinaemia on glucose oxidation (upper panel) and non-oxidative glucose disposal (bottom panel) in the basal state and during the three step euglycaemic insulin clamp studies carried out after (四) vs before ( $\square$ ) chronic insulin infusion. * $p<0.01$, $\dagger p<0.001, * * p<0.05$
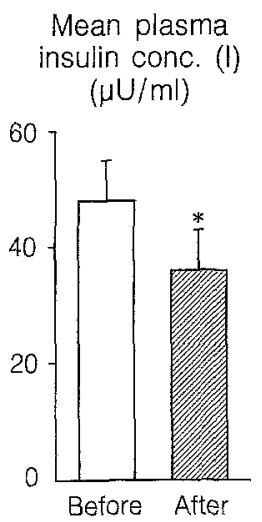

Whole body glucose metabolism (M) $\left(\mathrm{mg} \cdot \mathrm{kg}^{-1} \cdot \mathrm{min}^{-1}\right)$

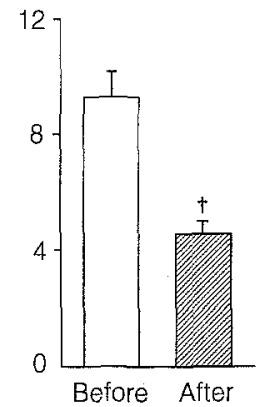

Insulin sensitivity index $(\mathrm{M} / \mathrm{I} \times 100)$

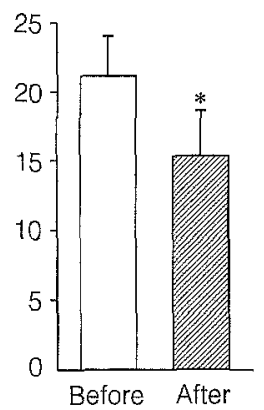

Fig. 5. Plasma insulin response (I), whole body glucose metabolism (M), and insulin sensitivity index (M/I ratio - 100) during hyperglycaemic clamp studies carried out before $(\square)$ and after (ख्र) $96 \mathrm{~h}$ constant insulin infusion. $* p<0.05, \uparrow p<0.001$ vs initial hyperglycaemic clamp study

in both studies. The early ( $0-10 \mathrm{~min})$ insulin response $(156 \pm 18 \mathrm{vs} 136 \pm 6 \mathrm{pmol} / \mathrm{l})$ was similar in the hyperglycaemic clamp studies performed before and after $96 \mathrm{~h}$ of constant insulin infusion. Both the late $(300 \pm 42$ vs $222 \pm 42 \mathrm{pmol} / 1, p<0.05)$ and total $(288 \pm 42$ vs $216 \pm 42 \mathrm{pmol} / \mathrm{l}, p<0.05)$ plasma insulin responses were significantly reduced following chronic insulin infusion (Fig.5). The total amount of glucose metabolized $(51.6 \pm 4.9$ vs $25.2 \pm 2.4 \mu \mathrm{mol}$. $\left.\mathrm{kg} \cdot{ }^{-1} \mathrm{~min}^{-1}, p<0.001\right)$ and the insulin sensitivity in$\operatorname{dex}\left(704 \pm 96\right.$ vs $510 \pm 110 \mu \mathrm{mol} \cdot \mathrm{kg} \cdot{ }^{-1} \mathrm{~min}^{-1}$ per $\mathrm{pmol} / 1, p<0.05)$ were significantly reduced after $96 \mathrm{~h}$ of sustained, physiologic hyperinsulinaemia while maintaining euglycaemia (Fig. 5).

\section{Chronic glucose infusion}

Plasma glucose and insulin concentrations. Fasting plasma glucose and insulin were $4.7 \pm 0.1 \mathrm{mmol} / 1$ and $42 \pm 6 \mathrm{pmol} / \mathrm{l}$, respectively. During the $6 \mathrm{~h}$ immediately following the start of glucose infusion $\left(16.7 \mu \mathrm{mol} \cdot \mathrm{kg} \cdot{ }^{-1} \mathrm{~min}^{-1}\right)$, the mean plasma glucose and insulin levels were $6.1 \pm 0.1 \mathrm{mmol} / \mathrm{l}$ and $108 \pm 6 \mathrm{pmol} / \mathrm{l}$, respectively. The time course of change in plasma glucose and insulin during the first $6 \mathrm{~h}$ of constant glucose infusion is shown in Figure 6. Mean plasma insulin on Days 1,2 , and 3 was $114 \pm 12,120 \pm 18$, and $132 \pm 12 \mathrm{pmol} / 1$, respectively, while plasma glucose was $6.1 \pm 0.1,5.9 \pm 0.1$, and $5.9 \pm 0.1 \mathrm{mmol} / \mathrm{l}$.

Hepatic glucose production (HGP). On the morning of Day 1, basal HGP was $12.3 \pm 0.3 \mu \mathrm{mol} \cdot \mathrm{kg} \cdot^{-1}$ $\mathrm{min}^{-1}$. After the start of glucose infusion, insulin secretion was stimulated and the combination of hyperglycaemia plus hyperinsulinaemia caused a prompt suppression of HGP (Fig.6), which averaged $1.5 \pm 0.3 \mu \mathrm{mol} \cdot \mathrm{kg}^{-1} \mathrm{~min}^{-1}$. On the morning of Days 2 and 3, HGP remained suppressed at $1.5 \pm 0.7$ and $1.4 \pm 0.3 \mu \mathrm{mol} \cdot \mathrm{kg} \cdot{ }^{-1} \mathrm{~min}^{-1}$. Basal Rd on Day 1 $\left(12.6 \pm 0.3 \mu \mathrm{mol} \cdot \mathrm{kg} \cdot{ }^{-1} \mathrm{~min}^{-1}\right)$ rose to a mean of $17.6 \pm 0.9$ during the initial $6 \mathrm{~h}$ of constant glucose infusion. The $\mathrm{Rd}$ on the morning of Day 2 (19.2 \pm

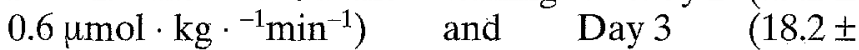
$0.9 \mu \mathrm{mol} \cdot \mathrm{kg} \cdot{ }^{-1} \mathrm{~min}^{-1}$ ) was similar to Day 1 . Basal glucose clearance, $2.62 \pm 0.09 \mathrm{ml} \cdot \mathrm{kg}^{-1} \cdot \mathrm{min}^{-1}$, rose to $3.03 \pm 0.16$ after $6 \mathrm{~h}$ of glucose infusion and remained unchanged on Days 2 and 3 at $3.33 \pm 0.10$ and $3.12 \pm 0.15 \mathrm{ml} \cdot \mathrm{kg}^{-1} \cdot \mathrm{min}^{-1}$, respectively.

Euglycaemic insulin clamp. During the baseline insulin clamp study, the fasting plasma insulin concentration, $48 \pm 6 \mathrm{pmol} / \mathrm{l}$, was raised to $174 \pm 18,270 \pm 24$, and $498 \pm 24 \mathrm{pmol} / \mathrm{l}$, respectively, during the $1.5,3$, and $6 \mathrm{nmol} \cdot \mathrm{kg}^{-1} \cdot \mathrm{min}^{-1}$ insulin infusion steps, while the fasting plasma glucose $(4.7 \pm 0.1 \mathrm{mmol} / \mathrm{l})$ was maintained at $4.7 \pm 0.1,4.7 \pm 0.1$, and $4.7 \pm 0.1 \mathrm{mmol} /$ 1 , respectively. During the repeat insulin clamp study performed after $48 \mathrm{~h}$ of constant glucose infusion, steady-state plasma insulin concentration during the three insulin infusion steps was $180 \pm 18,294 \pm 30$, and $528 \pm 42 \mathrm{pmol} / \mathrm{l}$, respectively, with plasma glucose of $4.7 \pm 0.1,4.8 \pm 0.1$, and $4.7 \pm 0.1 \mathrm{nmol} / \mathrm{l}$. The CVs for plasma glucose and insulin concentrations were less than $5 \%$ and $7 \%$, respectively, in all subjects.

During the initial insulin clamp protocol, basal HPG $\left(11.3 \pm 1.0 \mu \mathrm{mol} \cdot \mathrm{kg} \cdot{ }^{-1} \mathrm{~min}^{-1}\right)$ declined to $2.4 \pm 0.9,0.7 \pm 0.5$, and $0.6 \pm 0.4 \mu \mathrm{mol} \cdot \mathrm{kg} \cdot{ }^{-1} \mathrm{~min}^{-1}$ during the $1.5,3$, and $6 \mathrm{nmol} \cdot \mathrm{kg}^{-1} \cdot \mathrm{min}^{-1}$ insulin infusion steps. During the repeat insulin clamp study performed after $48 \mathrm{~h}$ of constant glucose infusion HPG was suppressed to $2.9 \pm 1.2,0.7 \pm 0.4,0.6 \pm$ 

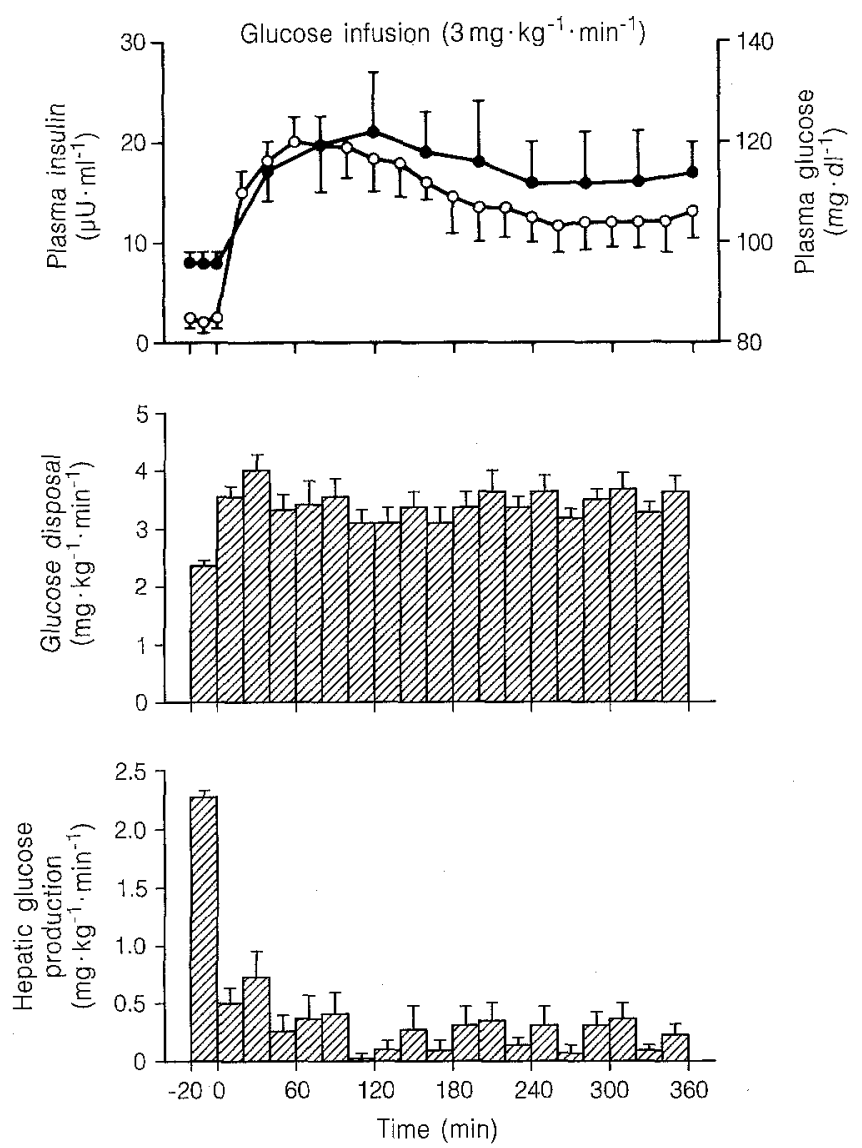

Fig. 6. Time course of change in plasma glucose $(-\circ)$ and insulin (--) concentrations, whole body glucose disposal, and HGP during the $6 \mathrm{~h}$ period immediately following the start of the constant glucose infusion
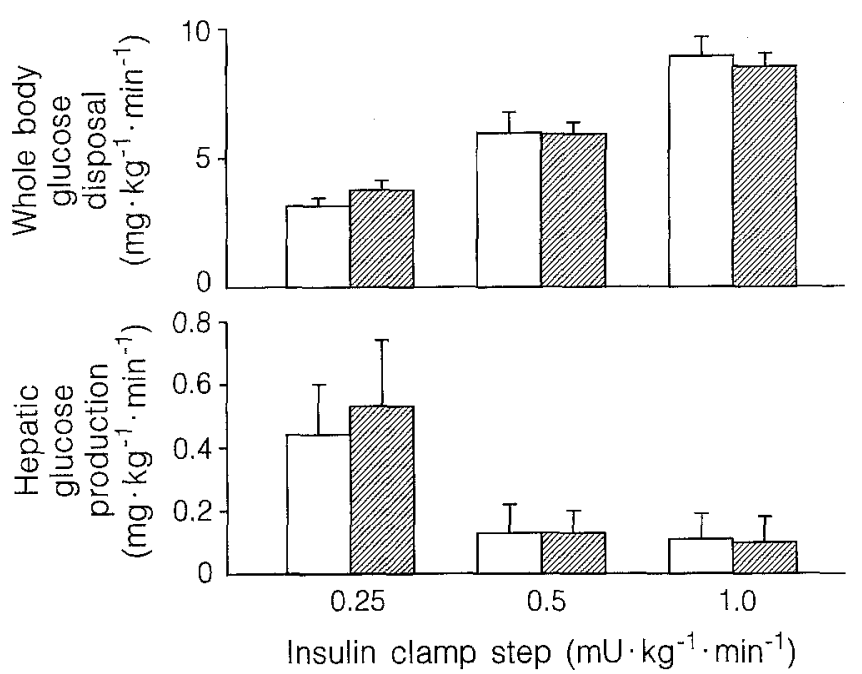

Fig. 7. Whole body glucose disposal and HGP during the three-step euglycaemic insulin clamp study performed before ([) and after (10) $48 \mathrm{~h}$ of constant glucose infusion

$0.4 \mu \mathrm{mol} \cdot \mathrm{kg} \cdot{ }^{-1} \mathrm{~min}^{-1}$, respectively $(p=\mathrm{NS})$. Basal $\operatorname{Rd}\left(11.3 \pm 1.0 \mu \mathrm{mol} \cdot \mathrm{kg} \cdot{ }^{-1} \mathrm{~min}^{-1}\right)$ during the initial insulin clamp study rose to $17.6 \pm 1.7,33.1 \pm 4.5$, and $49.5 \pm 4.0 \mu \mathrm{mol} \cdot \mathrm{kg} \cdot{ }^{-1} \mathrm{~min}^{-1}$ during the $1.5,3$, and
$6 \mathrm{nmol} \cdot \mathrm{kg}^{-1} \cdot \mathrm{min}^{-1}$ insulin infusion steps $(p<0.01$ vs each preceding step) (Fig. 7). During the repeat insulin clamp study performed after $48 \mathrm{~h}$ of constant glucose infusion, $\mathrm{Rd}$ rose to $20.9 \pm 2.0,32.8 \pm 2.6$, and $47.3 \pm 2.8 \mu \mathrm{mol} \cdot \mathrm{kg} \cdot{ }^{-1} \mathrm{~min}^{-1} \quad(p<0.01$ vs each preceding step) ( $p=\mathrm{NS}$ vs initial insulin clamp study) (Fig. 7).

Basal glucose oxidation during the initial insulin clamp study was $6.0 \pm 1.6 \mu \mathrm{mol} \cdot \mathrm{kg} \cdot{ }^{-1} \mathrm{~min}^{-1}$ and remained unchanged $(6.3 \pm 1.5)$ during the lowest insulin infusion step; during the 3 and $6 \mathrm{nmol} \cdot \mathrm{kg}^{-1}$. $\mathrm{min}^{-1}$ insulin clamp steps, glucose oxidation increased to $10.2 \pm 1.8$ ( $p<0.01$ vs preceding step) and $12.4 \pm 1.3$ ( $p<0.05$ vs preceding step) (Fig. 8). Following $48 \mathrm{~h}$ of constant glucose infusion basal glucose oxidation, $13.6 \pm 2.3 \mu \mathrm{mol} \cdot \mathrm{kg} \cdot{ }^{-1} \mathrm{~min}^{-1}$, was increased more than two-fold $(p<0.01)$ compared to the pre-glucose infusion study. Glucose oxidation rose to $16.9 \pm 1.5$ ( $p<0.05$ vs baseline), $19.4 \pm 1.7$ ( $p<0.05$ vs preceding step), and $20.0 \pm 1.8 \mu \mathrm{mol}$. $\mathrm{kg} \cdot{ }^{-1} \min ^{-1}(p=\mathrm{NS}$ vs preceding step) during the three insulin clamp steps (all $p<0.01$ vs corresponding value during the initial insulin clamp protocol) (Fig. 8).

During the initial insulin clamp study basal nonoxidative glucose disposal $(5.8 \pm 1.1 \mu \mathrm{mol} \cdot \mathrm{kg}$. ${ }^{-1} \mathrm{~min}^{-1}$ ) increased to $11.3 \pm 1.1,25.3 \pm 3.8$, and $40.9 \pm 3.8 \mu \mathrm{mol} \cdot \mathrm{kg}^{-1} \mathrm{~min}^{-1}$ during the $1.5,3$ and $6 \mathrm{nmol} \cdot \mathrm{kg}^{-1} \cdot \min ^{-1}$ insulin infusion steps (each $p<0.01$ vs the preceding value) (Fig. 8). Following $48 \mathrm{~h}$ of constant glucose infusion basal non-oxidative glucose disposal decreased to $4.8 \pm 0.7 \mu \mathrm{mol} \cdot \mathrm{kg}$. ${ }^{-1} \mathrm{~min}^{-1}$ ( $p<0.01$ vs pre-glucose infusion) and the insulin-stimulated rate of non-oxidative glucose disposal was markedly reduced during each of the three insulin clamp steps: $7.7 \pm 1.2,15.4 \pm 2.9$, and $30.7 \pm$ $3.8 \mu \mathrm{mol} \cdot \mathrm{kg} \cdot{ }^{-1} \mathrm{~min}^{-1}$ (all $p<0.01$ vs the corresponding value during the initial insulin clamp protocol) (Fig. 8).

During the initial insulin clamp study basal lipid oxidation $\left(0.93 \pm 0.22 \mu \mathrm{mol} \cdot \mathrm{kg} \cdot{ }^{-1} \mathrm{~min}^{-1}\right)$ decreased to $0.79 \pm 0.22$ ( $p<0.05$ vs basal), $0.54 \pm 0.16$ ( $p<0.05$ vs preceding step), and $0.47 \pm 0.13$, respectively, during the $1.5,3$, and $6 \mathrm{nmol} \cdot \mathrm{kg}^{-1} \cdot \mathrm{min}^{-1}$ insulin clamp steps. Following $48 \mathrm{~h}$ of constant glucose infusion basal lipid oxidation fell to $0.37 \pm 0.17 \mu \mathrm{mol} \cdot \mathrm{kg}$. ${ }^{-1} \min ^{-1}$ ( $p<0.01$ vs pre-glucose infusion) and during all three insulin clamp steps lipid oxidation $(0.21 \pm 0.10,0.10 \pm 0.07$, and $0.08 \pm 0.06 \mu \mathrm{mol} \cdot \mathrm{kg}$. $\left.{ }^{1} \mathrm{~min}^{-1}\right)$ was significantly reduced $(p<0.01)$ vs the corresponding value during the initial insulin clamp study. In the initial insulin clamp study the basal non-protein respiratory quotient (NPRQ) was $0.82 \pm 0.03$ and rose progressively during each insulin clamp step to $0.84 \pm 0.05,0.86 \pm 0.03$ and $0.90 \pm 0.02$. The basal NPRQ $(0.93 \pm 0.04)$ following $48 \mathrm{~h}$ of glucose infusion was significantly increased $(p<0.01)$ and during each insulin clamp step the NPRQ 

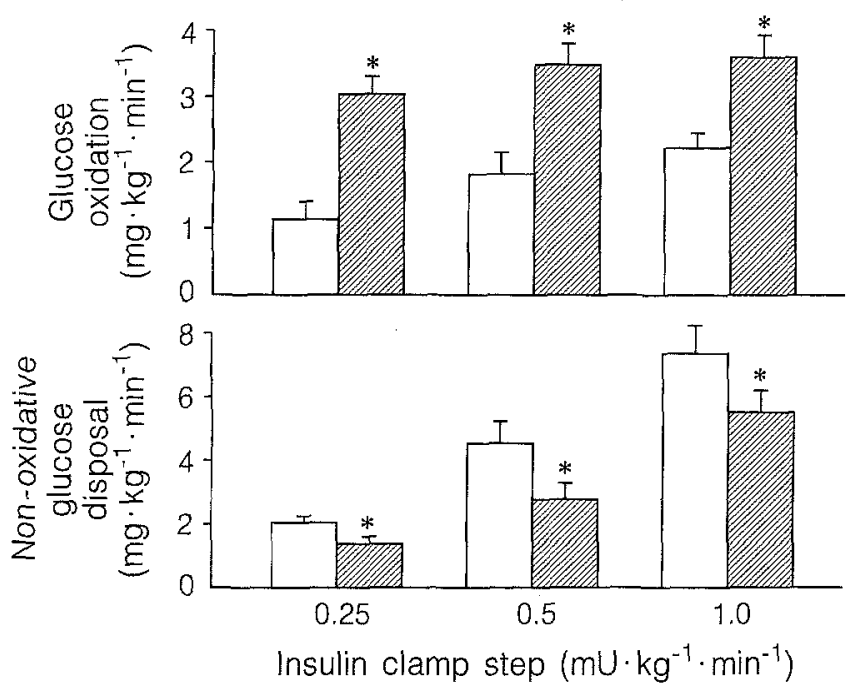

Fig. 8. Glucose oxidation and non-oxidative glucose disposal during the three-step euglycaemic insulin clamp carried out before $(\square)$ and after (曾) $48 \mathrm{~h}$ of constant glucose infusion. * $p<0.01$ vs initial insulin clamp study

exceeded $1.00(1.01 \pm 0.04,1.03 \pm 0.05$, and $1.04 \pm$ $0.05)$, indicating net lipid synthesis.

Hyperglycaemic clamp. The fasting plasma glucose, $4.8 \pm 0.1 \mathrm{mmol} / 1$, was acutely raised and kept at $11.7 \pm 0.1$ and $12.0 \pm 0.1 \mathrm{mmol} / \mathrm{l}(\mathrm{CV}<5 \%)$, respectively, in the hyperglycaemic clamp studies performed before and after $72 \mathrm{~h}$ of constant glucose infusion. Fasting plasma insulin concentration, $42 \pm 6 \mathrm{pmol} / \mathrm{l}$, was similar in both studies. The early (282 \pm 48 vs $168 \pm 60 \mathrm{pmol} / \mathrm{l}, p<0.01)$, late $(612 \pm$ 102 vs $276 \pm 48 \mathrm{pmol} / \mathrm{l}, p<0.01)$, and total $(582 \pm 102$ vs $264 \pm 48 \mathrm{pmol} / 1, p<0.01$ ) plasma insulin responses were significantly greater during the hyperglycaemic clamp performed after $72 \mathrm{~h}$ of constant glucose infusion. The total amount of glucose metabolized $\left(82.3 \pm 8.8\right.$ vs $\left.45.4 \pm 7.2 \mu \mathrm{mol} \cdot \mathrm{kg} \cdot{ }^{-1} \mathrm{~min}^{-1}, p<0.01\right)$ was $81 \%$ greater during the hyperglycaemic clamp performed after chronic glucose infusion. However, the insulin sensitivity index was similar in the hyperglycaemic clamp studies performed after (594士 $63 \mu \mathrm{mol} \cdot \mathrm{kg} \cdot{ }^{-1} \mathrm{~min}^{-1}$ per $\mathrm{pmol} / \mathrm{l}$ ) vs before $(637 \pm$ 121) the chronic glucose infusion.

Plasma triglyceride and cholesterol concentrations. Prior to the start of the $72 \mathrm{~h}$ constant glucose infusion, the fasting plasma triglyceride was $0.92 \pm 0.19 \mathrm{~g} / \mathrm{l}$. Plasma triglyceride concentration was $1.17 \pm 0.22$ and $1.19 \pm 0.19 \mathrm{~g} / 1$ at 48 and $72 \mathrm{~h}$ respectively, after the start of the constant glucose infusion, ( $p<0.01$ vs baseline). Fasting plasma cholesterol $(4.99 \pm 0.15 \mathrm{mmol} / \mathrm{l})$ remained unchanged after 48 and $72 \mathrm{~h}(4.99 \pm 0.15$ and $4.66 \pm 0.20 \mathrm{mmol} / 1$, respectively; $p=$ NS vs baseline) of continuous glucose infusion.

\section{Discussion}

Insulin resistance and hyperinsulinaemia are part of an intertwined metabolic web that includes NIDDM, obesity, hypertension, dyslipidaemia, and cardiovascular disease [1-3, 10-12]. It generally is thought that insulin resistance represents the primary disturbance, while hyperinsulinaemia is a compensatory response by the beta cells to offset the defect in insulin action and maintain a normal flux of glucose into the cell. However, recent evidence suggests that hyperinsulinaemia per se may lead to the development of insulin resistance [13-18].

In the present study we infused insulin exogenously to create physiologic hyperinsulinaemia (120 $\pm 12 \mathrm{pmol} / \mathrm{l})$ for $96 \mathrm{~h}$ while maintaining strict euglycaemia $(4.8 \pm 0.1 \mathrm{mmol} / \mathrm{l})$. Since the plasma glucose was monitored frequently (at least every $1-2 \mathrm{~h}$ ) throughout the day, hypoglycaemia was avoided, and observed defects in insulin action could not be related to the release of counterregulatory hormones. The magnitude, as well as the pattern of elevation in plasma insulin concentration was chosen to simulate the sustained increase in fasting insulin observed in NIDDM and obese individuals [1,2]. During the first $6 \mathrm{~h}$ after the start of insulin infusion there was a progressive rise in whole body glucose disposal and a prompt, complete suppression of HGP (Fig. 2); however, within $48 \mathrm{~h} \mathrm{Rd}$ had declined by $18 \%(p<0.01)$ and at $72 \mathrm{~h}$ a further decrease (by $28 \%$ ) in Rd had occurred. Thus, exposure to continuous, physiologic hyperinsulinaemia for as little as $48 \mathrm{~h}$ led to the development of impaired insulin action. The suppressive effect of insulin on HGP did not wane with time, indicating that the insulin resistance resided in peripheral tissues. Whether more prolonged insulin infusion (>72 h) and/or a greater magnitude of hyperinsulinaemia would lead to the development of hepatic insulin resistance cannot be excluded by the present study. It is also likely that the concomitant development of hypoglucagonaemia may have masked the presence of hepatic insulin resistance.

During each insulin clamp step, whole body insulin-mediated glucose disposal was significantly reduced (by $20-40 \%$ ) following $72 \mathrm{~h}$ of chronic insulin infusion (Fig. 3), and a similar decrease (28\%) in the insulin sensitivity index was observed during the hyperglycaemic clamp (Fig. 5). Since during i.v. glucose infusion (under both euglycaemic hyperinsulinaemic and hyperglycaemic hyperinsulinaemic conditions) over $80 \%$ of the infused glucose is disposed of in muscle $[36,37]$, it follows that muscle tissue must represent the primary site of insulin resistance following chronic exposure to insulin. Suppression of HGP by insulin was not impaired at any hyperinsulinaemic plateau (Fig. 3).

Following $72 \mathrm{~h}$ of chronic euglycaemic hyperinsulinaemia basal glucose oxidation increased by $95 \%$ 
and non-oxidative glucose disposal declined by $66 \%$ (both $\mathrm{p}<0.01)$. During the lowest $\left(1.5 \mathrm{nmol} \cdot \mathrm{kg}^{-1}\right.$. $\mathrm{min}^{-1}$ ) insulin infusion step of the initial insulin clamp study, glucose oxidation and non-oxidative glucose disposal increased $38 \%$ and $70 \%$, respectively (Fig. 4). Following $72 \mathrm{~h}$ of exposure to constant hyperinsulinaemia the ability of the same insulin dose to augment non-oxidative glucose disposal was completely abolished, while the stimulatory effect of insulin on glucose oxidation was enhanced by $108 \%$ (Fig. 4). At the two higher insulin clamp steps (3 and $6 \mathrm{nmol} \cdot \mathrm{kg}^{-1} \cdot \mathrm{min}^{-1}$ ) insulin-mediated glucose oxidation also was augmented and all of the insulin resistance was accounted for by impaired non-oxidative glucose disposal (Fig.4). These divergent effects of insulin on glucose oxidation (enhanced) and non-oxidative glucose disposal (reduced) suggest a post-glucose transport/phosphorylation defect in insulin action. If decreased insulin receptor number/function, or impaired insulin receptor signal transduction, or reduced glucose transport/phosphorylation were responsible for the insulin resistance, both glucose oxidation and non-oxidative glucose disposal should be diminished proportionately. Our findings suggest the presence of a specific intracellular defect in the glycogen synthetic pathway. It is noteworthy that in obese people [38-40], in individuals with the insulin resistance syndrome [10-12], in lean subjects with impaired glucose tolerance $[1-4,6-8,41]$, in the normal glucose tolerant offspring of two NIDDM parents [42], and in the first degree relatives of NIDDM subjects [5], a specific defect in the non-oxidative or glycogen synthetic pathway has been consistently demonstrated. In patients with NIDDM, impaired glucose tolerance, and obesity [1-9], hyperinsulinaemia has generally been considered to represent a compensatory response to insulin resistance. However, the present findings indicate that the "compensatory" hyperinsulinaemia must be considered an important pathogenic factor which can lead to a worsening of the insulin resistance, whatever its origin. It is of note that diminished non-oxidative glucose disposal can be induced by plasma insulin concentrations $(120 \pm 12 \mathrm{pmol} / \mathrm{l})$ which are well within the range of fasting insulin levels observed in diabetic $[1,2]$ and obese [30-33] individuals. This lends further credence to the self-perpetuating role of hyperinsulinae$\mathrm{mia}$ in the insulin resistance in these two common metabolic disorders.

The present results also clarify the role of chronic hyperglycaemia in the development of insulin resistance. Following $48 \mathrm{~h}$ of sustained, physiologic hyperglycaemic (mean glucose $=6.1 \pm 0.1 \mathrm{mmol} / 1$; increment $=1.4 \pm 0.1 \mathrm{mmol} / \mathrm{l}) \quad$ hyperinsulinaemia whole body insulin-mediated glucose disposal (euglycaemic insulin clamp) was unchanged (Fig.7). However, there was a marked alteration in the intracellular partitioning of glucose between the oxida- tive and non-oxidative (glycogen synthetic) pathways. Glucose oxidation increased by $32-100 \%$ during each insulin clamp step (Fig. 8), whereas non-oxidative glucose disposal was markedly reduced (Fig. 8). The effect of chronic (48 h) hyperglycaemic hyperinsulinaemia on insulin sensitivity can best be appreciated by comparing the results obtained with that following chronic insulin infusion. Following chronic hyperglycaemic hyperinsulinaemia, the rise in insulin-stimulated glucose oxidation (Fig. 8) was significantly greater than the increase observed following $72 \mathrm{~h}$ of euglycaemic hyperinsulinaemia (Fig.4). In addition, combined hyperglycaemic hyperinsulinaemia (Fig. 8) blunted the decline in insulin-mediated glycogen synthesis observed following $72 \mathrm{~h}$ of euglycaemic hyperinsulinaemia (Fig.4). These results indicate that, in the presence of combined hyperglycaemia plus hyperinsulinaemia, it is the hyperinsulinaemia (and not the hyperglycaemia) that causes the impairment in glycogen synthesis. These findings may appear to be in conflict with the reported role of hyperglycaemia in the development of insulin resistance [22]. However, most previous studies have examined the effect of chronic hyperglycaemia in the presence of insulinopenia and used much higher levels of hyperglycaemia than employed here.

Both chronic insulin infusion and chronic glucose infusion led to a suppression of basal lipid oxidation and a more effective inhibition of lipid oxidation by insulin during each insulin clamp step. Combined hyperglycaemic hyperinsulinaemia had a greater inhibitory effect on lipid oxidation than euglycaemic hyperinsulinaemia alone, suggesting an independent effect of hyperglycaemia to suppress fat oxidation. Following both chronic glucose and insulin infusion the basal rate of lipid oxidation was strongly and inversely correlated with the basal rate of glucose oxidation $(\mathrm{r}=-0.784, \mathrm{p}<0.001)$. During the three-step insulin clamp study performed after chronic insulin infusion $(\mathrm{r}=-0.833, \mathrm{p}<0.001)$ and after chronic glucose infusion $(r=-0.450, p<0.05)$ lipid and glucose oxidation were also inversely correlated, suggesting that the stimulatory effects of hyperinsulinaemia and hyperglycaemia on glucose oxidation were, in part, mediated via the Randle cycle [43]. Since lipid oxidation is increased (not decreased) in NIDDM [1, 2, 39], one should not draw any analogies between the effect of combined hyperglycaemic hyperinsulinaemia on glucose oxidation in normal subjects and the situation in NIDDM subjects in whom combined hyperglycaemic hyperinsulinaemia occurs in the presence of an elevated rate of lipid oxidation.

Following chronic insulin infusion the NPRQ during each insulin clamp step was significantly increased. However, at no time did the NPRQ exceed 1.0 , indicating no net lipid synthesis. In contrast, following chronic glucose infusion the NPRQ exceeded 
1.0 during each insulin clamp step, indicating net lipid synthesis. Consistent with this, the plasma triglyceride concentration rose significantly. These observations indicate that the ability of chronic, physiologic hyperinsulinaemia to stimulate net lipid synthesis requires the presence of concomitant hyperglycaemia. They also indicate a role for hyperinsulinaemia in the development of hypertriglyceridaemia [3, 10-12]. These observations, are in agreement with in vivo and in vitro studies which have shown that both insulin [44] and glucose [45] act independently to enhance hepatic VLDL synthesis.

In healthy young subjects with no family history of diabetes and presumably with no genetic beta-cell abnormality, chronic $(72 \mathrm{~h}$ ) physiologic hyperglycaemia caused a marked potentiation of both the early and late plasma insulin responses to an acute hyperglycaemic stimulus. Since the metabolic insulin clearance rate was unchanged, it can be assumed that the decreased plasma insulin response reflects impaired beta cell insulin secretion. The augmented plasma insulin response to acute hyperglycaemia following $72 \mathrm{~h}$ of glucose infusion may appear to be in contrast to some animal studies where a similar duration (72 h) of hyperglycaemia was shown to impair insulin secretion [22-24]. However, in these studies [2224] glucose was infused chronically in rats which had undergone a partial pancreatectomy or had received low dose streptozotocin to reduce beta-cell mass and the magnitude of the hyperglycaemia was much greater than in the present study. These observations suggest that chronic hyperglycaemia induces a defect in insulin secretion only in the presence of a diminished number of beta cells or in a genetically predisposed beta cell. Insulin is known to inhibit beta cell secretion [46]; however, despite concomitant hyperinsulinaemia, chronic glucose infusion still enhanced the ability of an acute i.v. glucose stimulus to stimulate insulin secretion. The true effect of chronic hyperinsulinaemia on beta-cell secretion is evident from the study in which insulin was infused and euglycaemia was maintained. In this study insulin secretion was diminished by $25 \%$.

In summary, the present results indicate that chronic, sustained, physiologic euglycaemic hyperinsulinaemia for as little as $48-72 \mathrm{~h}$ is capable of inducing significant insulin resistance affecting the glycogen synthetic pathway. If this insulin resistance were to persist indefinitely, then hyperinsulinaemia should be considered, not only a compensatory response to the presence of insulin resistance, but a self-perpetuating cause of the defect in insulin action.

Acknowledgements. The authors would like to thank Ms. L. Olivarri for expert secretarial assistance in preparation of the manuscript. We gratefully acknowledge the nursing and the administrative staff of the GCRC for the excellent care of our subjects. This work was supported in part by NIH-grants
AM24092 and AG00233. Clinical Research Center grant \#M01-RR-01346, the GRECC, funds from the VA Medical Research Service, and a VA Merit Award.

\section{References}

1. DeFronzo RA, Bonadonna RC, Ferrannini E (1992) Pathogenesis of NIDDM. A balanced overview. Diabetes Care 15: $318-368$

2. DeFronzo RA (1988) The triumvirate: $\beta$-cell, muscle, liver. A collusion responsible for NIDDM. Diabetes 37: 667-687

3. Reaven GM (1988) Role of insulin resistance in human disease. Diabetes 37: 1595-1607

4. Lillioja S, Mott DM, Howard BV et al. (1988) Impaired glucose tolerance as a disorder of insulin action: longitudinal and cross-sectional studies in Pima Indians. N Engl J Med 318: 1217-1225

5. Eriksson J, Franssila-Kallunki A, Ekstrand A et al. (1989) Early metabolic defects in persons at increased risk for non-insulin-dependent diabetes mellitus. $\mathrm{N}$ Engl J Med 321: $337-343$

6. Saad MF, Knowler WC, Pettitt DJ, Nelson RG, Mott DM, Bennett PH (1989) Sequential changes in serum insulin concentration during development of non-insulin-dependent diabetes. Lancet 1: 1356-1359

7. Sicree RA, Zimmet P, King HO, Coventry JO (1987) Plasma insulin response among Nauruans: prediction of deterioration in glucose tolerance over 6 yr. Diabetes 36: 179-186

8. Saad MF, Knowler WC, Pettitt DJ, Nelson RG, Mott DM, Bennett PH (1988) The natural history of impaired glucose tolerance in the Pima Indians. N Engl J Med 319: 1500-1505

9. Haffner SM, Stern MP, Hazuda HP, Mitchell BD, Patterson JK (1988) Increased insulin concentrations in non-diabetic offspring of diabetic parents. N Engl J Med 319: 1297-1301

10. DeFronzo RA, Ferrannini E (1991) Insulin resistance. A multifaceted syndrome responsible for NIDDM, obestiy, hpyertension, dyslipidemia, and atherosclerotic cardiovascular disease. Diabetes Care 14: 173-194

11. DeFronzo RA (1992) Insulin resistance, hyperinsulinemia, and coronary artery disease: a complex metabolic web. Coronary Artery Disease 3: 11-25

12. Ferrannini E, Haffner SM, Mitchell BD, Stern MP (1991) Hyperinsulinaemia: the key feature of a cardiovascular and metabolic syndrome. Diabetologia 3: 416-422

13. Garvey WT, Olefsky JM, Marshall S (1986) Insulin induces progressive insulin resistance in cultured rat adipocytes. Sequential effects at receptor and multiple postreceptor sites. Diabetes 35: 258-267

14. Wardzala LJ, Hirshman M, Pofcher E et al. (1985) Regulation of glucose utilization in adipose cells and muscle after long-term experimental hyperinsulinemia in rats. J Clin Invest $76: 460-469$

15. McGuinness OP, Myers SR, Neal D, Cherrington AD (1990) Chronic hyperinsulinemia decreases insulin action but not insulin sensitivity. Metabolism 39: 931-937

16. Rizza RA, Mandarino LJ, Genest J, Baker BA, Gerich JE (1985) Production of insulin resistance by hyperinsulinaemia in man. Diabetologia 28: 70-75

17. Marangou AG, Weber KM, Boston RC et al. (1986) Metabolic consequences of prolonged hyperinsulinemia in humans. Evidence for induction of insulin insensitivity. Diabetes 35: 1383-1389

18. DelPrato S, Riccio A, Vigilli de Kreutzenberg $\mathrm{S}$ et al. (1993) Mechanisms of fasting hypoglycemia and concomi- 
S. Del Prato et al.: Chronic hyperinsulinaemia induces insulin resistance

tant insulin resistance in insulinoma patients. Metabolism 42: 24-29

19. Trimble ER, Weir GC, Gjinovci A, Assimacopoulos-Jeannet F, Benzi R, Renold AE (1984) Increased insulin responsiveness in vivo and in vitro consequent to induced hyperinsulinemia in the rat. Diabetes 33: 444-449

20. Ward GM, Walters JM, Aitken PM, Best JD, Alford FP (1990) Effects of prolonged pulsatile hyperinsulinemia in humans. Enhancement of insulin sensitivity. Diabetes 39: 501-507

21. Nomura M, Greenberg GR, Bahoric A, Albisser M (1986) The metabolic and hormonal adaptations of normal dogs to long-term exogenous sulfated insulin infusions. Metabolism 35: 892-898

22. Rossetti L, Giaccari A, DeFronzo RA (1990) Glucose toxicity. Diabetes Care 13: 610-630

23. Rossetti L, Shulman GI, Zawalich W, DeFronzo RA (1987) Effect of chronic hyperglycemia on in vivo insulin secretion in partially pancreatectomized rats. J Clin Invest 80: 10371044

24. Leahy JL (1990) Natural history of beta cell dysfunction in NIDDM. Diabetes Care 13: 992-1010

25. Rossetti L, Smith D, Shulman GI, Papachristou D, DeFronzo RA (1987) Correction of hyperglycemia with phlorizin normalizes tissue sensitivity to insulin in diabetic rats. $\mathrm{J}$ Clin Invest 79: 1510-1515

26. Kahn B, Shulman GJI, DeFronzo RA, Cushman SW, Rossetti L (1991) Normalization of blood glucose in diabetic rats with phlorizin treatment reverses insulin resistant glucose transport in adipose cells without restoring glucose transporter gene expression. J Clin Invest 87: 561-570

27. Yki-Jarvinen H, Helve E, Koivisto VA (1987) Hyperglycemia decreases glucose uptake in type I diabetes. Diabetes 36: 892-896

28. DeFronzo RA, Tobin JD, Andres R (1979) The glucose clamp technique. A method for quantifying insulin secretion and resistance. Amer J Physiol 6: E214-E223

29. Simonson DC, DeFronzo RA (1990) Measurement of substrate oxidation and energy expenditure in man by indirect calorimetry: practical and theoretical considerations. Am J Physiol 258: E399-E412

30. Somogyi M (1945) Determination of blood sugar. J Biol Chem 160: 69-73

31. Black CA, Banach W, Landt K, Devashar J, Sperling MA (1986) Effect of fetal insulin infusion on glucose kinetics in pregnant sheep: a compartmental analysis. Amer J Physiol 251: E448-E456

32. Hales CN, Randle PJ (1963) Immunoassay of insulin with insulin antibody precipitate. Biochemical J 88: 137-146

33. Tamborlane WV, Sherwin RS, Genel M, Felig P (1979) Restoration of normal lipid and amino acid metabolism in diabetic patients treated with a portable insulin infusion pump. Lancet I: 1258-1261
34. Steele R (1959) Influence of glucose loading and of injected insulin on hepatic glucose output. Ann NY Acad Sci 82: $420-430$

35. Shulman GI, Rothman DL, Jue T, Stein P, DeFronzo RA, Shulman RG (1990) Quantitation of muscle glycogen synthesis in normal subjects and subjects with non-insulindependent diabetes by ${ }^{13} \mathrm{C}$ nuclear magnetic resonance spectroscopy. N Engl J Med 322: 223-228

36. DeFronzo RA, Ferrannini E, Hendler R, Felig P, Wahren J (1983) Regulation of splanchnic and peripheral glucose uptake by insulin and hyperglycemia. Diabetes 32: 35-45

37. DeFronzo RA, Jacot E, Jequier E, Maeder E, Wahren J, Felber JP (1981) The effect of insulin on the disposal of intravenous glucose: results from indirect calorimetry and hepatic and femoral venous catheterization. Diabetes 30: $1000-1007$

38. Bogardus C, Lillioja S, Howard BV, Reaven G, Mott D (1984) Relationships between insulin secretion, insulin action, and fasting plasma glucose concentration in non-diabetic and non-insulin-dependent diabetic subjects. J Clin Invest 74: 1238-1246

39. Golay A, Felber JP, Jequier E, DeFronzo RA, Ferrannini E (1988) Metabolic basis of obesity and noninsulin-dependent diabetes mellitus. Diabetes Metab Rev 4: 727-747

40. Bonadonna RC, Groop L, Kraemer N, Ferrannini E, Del Prato S, DeFronzo RA (1990) Obesity and insulin resistance in man: a dose response study. Metabolism 39: 452459

41. Lillioja A, Mott DM, Zawadzki JK, Young AA, Abbott WG, Bogardus C (1986) Glucose storage is a major determinant of in vivo "insulin resistance" in subjects with normal glucose tolerance. J Clin Endocrinol Metab 62: $922-$ 927

42. Gulli G, Ferrannini E, Stern M, Haffner S, DeFronzo RA (1992) The metabolic profile of non-insulin-dependent diabetes mellitus is fully established in glucose tolerant offspring of two non-insulin dependent diabetic patients. Diabetes $41: 1575-1586$

43. Randle PJ, Garland PB, Hales CN, Newsholme EA (1963) The glucose fatty acid cycle: its role in insulin sensitivity and the metabolic disturbances of diabetes mellitus. Lancet I: $785-89$

44. Topping DL, Mayes RA (1972) The immediate effects of insulin and fructose on the metabolism of the perfused liver. Biochem J 126: 295-311

45. Woodside WF, Heimberg M (1976) Effects of anti-insulin serum, insulin, and glucose on output of triglycerides and on ketogenesis by the perfused rat liver. J Biol Chem 251: 12-32

46. Faber OK, Damsgaard EM (1984) Insulin secretion in type II diabetes. Acta Endocrinol [Suppl] 262: 47-50 